\title{
GROWTH CHARACTERISTICS AND DYNAMICS OF PROTEIN SYNTHESIS IN CALLUS CULTURES FROM Glycine wightii (Wight \& Arn.) Verdc.
}

\author{
Características do crescimento e dinâmica da síntese de proteínas em cultura de calos de \\ Glycine wightii (Wight \& Arn.) Verdc.
}

\author{
André Luis Coelho da Silva ${ }^{1}$, Cecília Sulzbacher Caruso ${ }^{2}$, Renato de Azevedo Moreira ${ }^{3}$, Ana Cecília Góes Horta ${ }^{4}$
}

\begin{abstract}
Cotyledon explants were first cultured on MS medium supplemented with 4.52 M 2,4-D and $0.46 \mathrm{mM}$ kinetin. The development of the calli was followed $(0,4,8,12,16,20,24,28$ and 32 days after) and the growth curve was determined, based in fresh and dry weight. The growth curve presented sigmoidal form with four distinct phases. The highest growth percentage was observed at the exponential phase and the lowest at the stationary phase. These results indicated that cotyledon callus subculture should be performed 20 days after inoculation. The calli obtained after a period of 28 days were freeze dried, macerated and submitted to extraction with buffers of different $\mathrm{pH}$ values $(2.6 ; 4.0 ; 6.0 ; 8.0$ and 10.0$)$ and the proteins in the extracts were determined by Bradford method. The $\mathrm{pH} 8.0$ buffer was the most efficient to extract the largest amount of protein. The amino acid analyses calli showed a high content of aspartic acid and low content of metionin. The dynamics of protein synthesis in calli was followed by SDSPAGE electrophoresis.
\end{abstract}

Index terms: Glycine, Leguminosae, callogenesis, SDS-PAGE.

\section{RESUMO}

Explantes cotiledonários foram primeiramente cultivados em meio MS suplementado com 2,4-D 4,52 mM e cinetina 0,46 mM. O desenvolvimento dos calos foi acompanhado $(0,4,8,12,16,20,24,28$ até 32 dias após o subcultivo) e uma curva de crescimento foi determinada com base nos pesos fresco e seco dos calos. A curva de crescimento apresentou um padrão sigmoidal com quatro fases distintas. A maior porcentagem de crescimento foi observada na fase exponencial e a menor na fase estacionária. Estes resultados indicam que o subcultivo dos calos pode ser realizado 20 dias após a inoculação. Os calos obtidos após um período de 28 dias foram liofilizados, macerados e submetidos à extração de proteínas solúveis, utilizando tampões com diferentes valores de $\mathrm{pH}$ $(2,6 ; 4,0 ; 6,0 ; 8,0$ e 10,0) e o teor protéico dos extratos foi determinado pelo método de Bradford. O tampão $\mathrm{pH} 8,0$ foi o mais eficiente na extração de proteínas solúveis dos calos. A análise de aminoácidos mostrou que os calos apresentam um alto teor de ácido aspártico/ asparaina em um baixo teor de metionina. A dinâmica da síntese de proteínas nos calos foi acompanhada por ensaios eletroforéticos (SDS-PAGE).

Termos para indexação: Glycine, Leguminosae, calogênese, SDS-PAGE.

(Recebido para publicação em 4 de novembro de 2004 e aprovado em 26 de setembro de 2005)

\section{INTRODUCTION}

Glycine wightii is an important climbing vine-like perennial, belonging to the family Leguminosae, sub-family Papilionoideae, genus Glycine and sun-genus Bracteata. This species is indigenous to Africa an in Brazil is commonly called "perennial soybean" (FIGUEREDO, 2000).

The techniques of plant tissue culture possess an enormous potential for the plant improvement and can also be used as a tool for studing protein synthesis. Tissue culture, inclusive of in vitro cells, tissues and organs, is a convenient and effective means in breeding genetics, physiology and biochemistry of legumes and it can also contribute to production of biomass and metabolites.
In vitro culture of glycine species has been reported from cotyledons and hypocotyls (PANDEY \& BANSAL, 1992), leaves (HAMMATT et al., 1987). Although the in vitro tissue culture has been reports for different dicotyledonous and monocotyledonous species, the number of reports dealing with dynamics of proteins synthesis in callus culture is still low (PODDER et al., 1993, SAARE-SURMINSKI et al., 1999; SERRA et al., 2000). Callus and cell culture could not only be an alternate continuo source of proteins, but could also be an useful and important model system to study their regulation and biosynthesis (PODDER et al., 1993) and in biochemistry studies (SERRA et al., 2000).

'Engenheiro Agrônomo, Dr., Grupo de Biofísica Molecular e Espectroscopia /USP-IFSC, Cx. P. 369 - 13560-970, São Carlos, SP, Brasil alcoelho@if.sc.usp.br

${ }^{2}$ Dra.,USP-IFSC, Cx. P. 369 - 13560-970 - São Carlos, SP, Brasil.

3Professor Titular, Dr., LABLEC-DBBM/UFC, Cx. P. 6020 - 60451-970 - Fortaleza, CE - Brasil.

${ }^{4}$ Professora Adjunto, Dra., LABLEC-DBBM/UFC, Cx. P. 6020 - 60451-970 - Fortaleza, CE - Brasil. 
The objective of the present work was investigate the growth characteriscs of the callus cultrure from Glycine wightii and to follow the dynamics of the proteins synthesis during this growth. The interest in the present study is based on the fact that plant tissue and cell cultures could be a useful and important tool to study biochemical em physiological parameters associated with the cell growth and dynamics, such as, intracellular levels of proteins.

\section{MATERIALAND METHODS}

\section{Plant material}

Glycine wightii (Wight \& Arn.) Verdc. madure seeds were collected from plants growing in the city of São Carlos-SP (Brazil). The botanical identification was carried out at the Department of Botanic, Federal University of Viçosa (UFV).

\section{Germination conditions seeds}

The seeds were pretreated by imersion in concentrated sulfuric acid (98\%) for 20 minutes and washed exhaustively in running tap water. The seeds were sterilized with 2-2.5\% $\mathrm{NaClO}$ for $15 \mathrm{~min}$. After washing several times with sterile water, they were placed between two sheets of filter paper Whatman $3 \mathrm{M}$ moistened sterile destilled water and kept in Petri dishes, in the dark. The seedlings were harvested with 7 days old.

\section{Callus induction and maintenance}

Segments $(18 \pm 2 \mathrm{~mm})$ were taken from cotyledons of the seedlings and placed on solidified medium consisted of MS salts (MURASHIGE \& SKOOG, 1962) to supplemented with $4.52 \mathrm{mM} 2,4-\mathrm{D}, 0.46 \mathrm{mM}$ kinetin and $3 \%$ sucrose (SILVA et al., 2003). The medium was adjusted to $\mathrm{pH} 5.8$ with $1 \mathrm{~N} \mathrm{NaOH}$, autoclaved and dispensed in 100 x $15 \mathrm{~mm}$ petri dishes ( $25 \mathrm{ml}$ medium for dish). The cultures were incubated at $28 \pm 2^{\circ} \mathrm{C}$ in the dark. After 4 weeks, the developed calli of cotyledons were separated from explants and transferred to fresh medium of same composition. The calli were subcultured for an additional 4 weeks.

\section{Callus growth determination}

Cotyledon callus stocks established previously were used to determine the growth curves. Pieces of friable callus (similar size) were inoculated in the MS medium supplemented with $4.52 \mathrm{mM} 2,4-\mathrm{D}, 0.46 \mathrm{mM}$ kinetin and $3 \%$ sucrose. The culture was incubated at $28 \pm 2{ }^{\circ} \mathrm{C}$ in the dark. The development was monitored at 4 days intervals up to 32 days and a growth curve was determined based in fresh and dry weigh of the calli.

\section{Protein content determination}

The calli from cotyledon obtained after 28 days were lyophilized, macerated and submitted to extraction with $0.1 \mathrm{M}$ glycine- $\mathrm{HCl} \mathrm{pH}$ 2.6, 0.1 M NaOAc pH 4.0, 0.1 M $\mathrm{NaOAc} \mathrm{pH}$ 6.0, 0.1 M Tris-HCl pH 8.0 and $0.1 \mathrm{M}$ Na-borate pH 10.0 buffers, all containing $0.15 \mathrm{M} \mathrm{NaCl}$. The samples were sonicated for 1 hour and clarified by centrifugation at $12.000 \mathrm{x} g$ for $20 \mathrm{~min}$ at $4{ }^{\circ} \mathrm{C}$. The clear supernatants were used for determination of soluble protein content. The protein content in the different fractions was performed according to Bradford (1976), using bovine serum albumine (BSA) as standard.

\section{Dynamic of proteins synthesis}

The proteins synthesis in calli during the growth curve was followed by measurement of protein content (BRADFORD, 1976) and by sodium dodecyl sulfatepolyacrylamide gel electrophoresis (SDS-PAGE) as described by Laemmli (1970). The samples (10 mg of callus powder) were dissolved in $1 \mathrm{ml}$ of $0.1 \mathrm{M}$ Tris- $\mathrm{HCl} \mathrm{pH} \mathrm{8,2 \%}$ sodium dodecyl sulfate (SDS) buffer with $1 \%$ bmercaptoetanol and incubated at $100^{\circ} \mathrm{C}$ for $10 \mathrm{~min}$. Silver staining was performed as described by Blum et al. (1987). The identification of the components of the storage proteins in the total extracts from G. wightii seeds was made using a protein marker extracted from soybean (Glycine max). The approximate molecular weights of the b-coglycinin subunits corresponded to 76,72 and $53 \mathrm{kDa}$ for $\mathrm{a}$ ', $\mathrm{a}$ and $\mathrm{b}$-subunits and those of the glycinin subunits to 45 and $38 \mathrm{kDa}$ for the acidic, and $22 \mathrm{kDa}$ for the basic subunits, as previously described by Shuttuck-Edidens \& Beachy (1985).

\section{Amino acid composition}

Amino acid analysis was performed after hydrolysis at $110{ }^{\circ} \mathrm{C}$ of callus samples (in sealed glass tubes under $\mathrm{N} 2$ ) for $20 \mathrm{~h}$ in $6 \mathrm{M} \mathrm{HCl}$. After hydrolysis, $\mathrm{HCl}$ was removed by evaporation and the residue was analyzed, in a BIOCHROM 20 (Pharmacia) amino acid analyzer. Tryptophan was determined according to the method described by Pintér-Szakács \& Molnár-Perl (1990).

\section{Data analysis}

For callus growth and protein, the experiments were carried out at least two time with 5 replicates. Five plates ( 5 explants / plate) were used every 4 days during the culture period to measure the growth callus and protein contents. Means standard error were applied to analyze the data. 


\section{RESULTS AND DISCUSSION}

Growth curves of cotyledon calli were plot based on fresh and dry weights (Figure 1). Cotyledon calli presented sigmoid growth curves with lag, exponential, linear and stationary phases. The adaptive period (lag phase), in which the fresh and dry weight of calli increases slowly, occured up to 4th day for cotyledon calli . According to Sragg \& Allan (1993), the lag phase is considered an energy producer period. The fast growth phases (exponential and linear phases) occurred between 4th and 16th day. The exponential or biosynthetic phase is the period of maximum celular division and greatest growth rate of the calli, while the linear phase is the period in which the cells grow but the cellular division decreases (SCRAGG \& ALLAN, 1993). The stationary phase of cotyledon calli occurred between the 16th and 32nd day. In this phase, the rate of cellular division is gradually reduced and then remain constant. According to Smith (2000), in the stationary phase occurs deprivement of nutrients in culture medium and a reduction of the $\mathrm{O} 2$ amounts inside the cells.

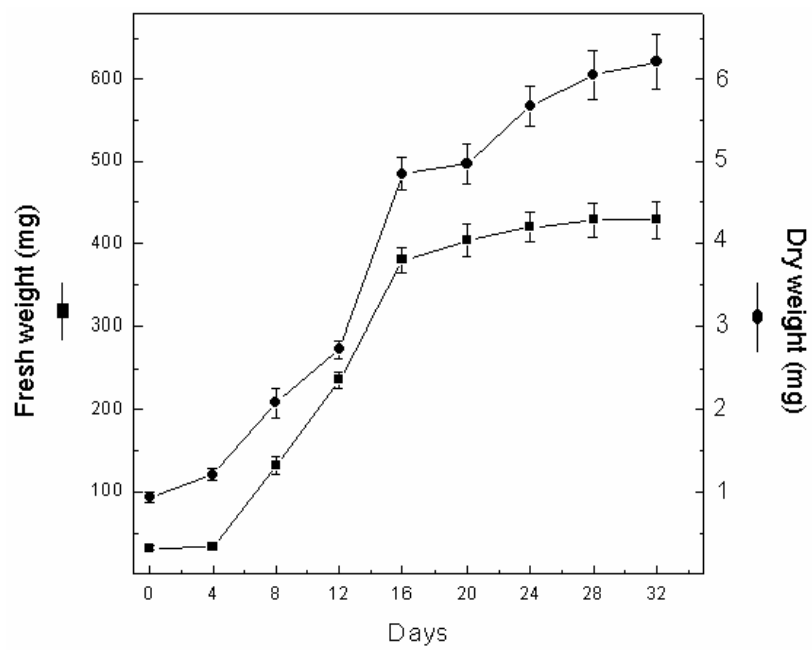

FIGURE 1 - Growth curves of the Glycine wightii cotyledon calli based on fresh ( $\square$ ) and dry (O) weight.

Figure 2 shows the influence of $\mathrm{pH}$ in the solubility of calli proteins. The protein content from Glycine wightii

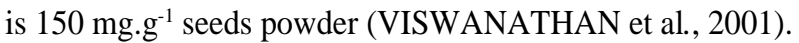
It was found a maximum (soluble) protein content at $\mathrm{pH}$ 8.0 (39.1 mgProtein. $\mathrm{g}^{-1}$ cotyledon calli powder) and a minimum content at $\mathrm{pH} 4.0$ (9.0 mgProtein. $\mathrm{g}^{-1}$ cotyledon calli ). Gupta \& Srivastava (1998) studing the calli from
Zizyphus mauritiana, also observed that the cotyledon calli had a higher protein content $\left(28.7\right.$ mgProtein. $\mathrm{g}^{-1}$ callus powder).

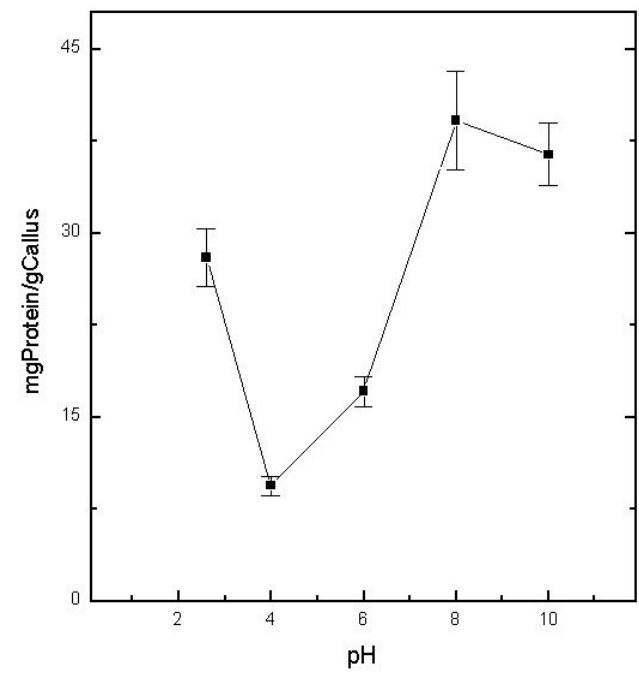

FIGURE 2 - Influence of $\mathrm{pH}$ on the solubility of Glycine wightii cotyledon calli proteins.

The protein content was analyzed during the growth callus (Figure 3 ). The results showed that between the 0 and 12 th day of culture there was a decrease in the protein content. This reduction possibly occurred due to an adaptation period of calli in the culture medium. The increase in the protein levels between 12th and 16th day of culture could be related to mitotic activity during the exponential and linear growth phases. Gutmann et al. (1996) also observed an increment in the protein levels in the cells of Larix leptoeuropaea during the first 2 weeks of culture, followed by a decrease of this content during the following weeks. The cell cycle is carried out by the synthesis of several new proteins that bring on morphological and biochemical changes in the cell during the mitotic activity. The decrease of the protein levels during to stationary phase correlates with the physiological stress related to diminishing nutrition in the medium, ageing and cell degeneration. Lal et al. (1992) also observed an increase in the protein level during the growth phase of the sugarcane callus and a decrease during the celular differentiation phase. 


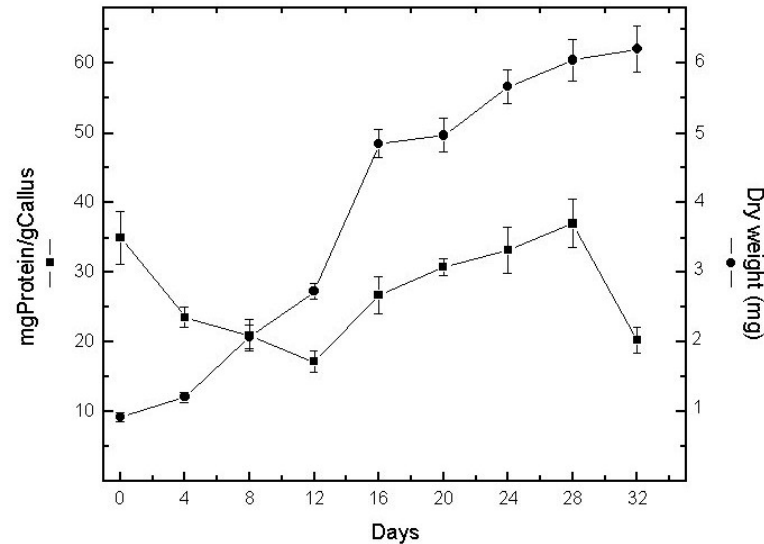

FIGURE 3 - Protein content of Glycine wightii cotyledon growth curve.

In cotyledon different days of the growth curves, SDS-PAGE analysis of the proteins extracts revealed some little change for the bands protein. Despite the differences observed, the protein patterns obtained from cotyledon calli powder electrophoresis (Figure 4-A2) were similar to proteins obtained from soybean and $G$. wightii seeds powder (Figure 4-A1), with predominance of bands with molecular mass characteristc of b-coglycinin (subunits corresponded to 76,72 and $53 \mathrm{kDa}$ for a', a and b-subunits) and those of the glycinin (subunits to 45 and $38 \mathrm{kDa}$ for the acidic, and $22 \mathrm{kDa}$ for the basic subunits), the main reserve proteins of soybean (BROOKS \& MORR, 1985). In particular, some protein bands started to disappear between 0 and 12th day in both cultures (Figures 4-A1). This reduction may have occurred due to the decrease of soluble protein during that period. Between the 12th and 28th day of the callus culture, it was observed that protein bands with molecular weights between 94 and $20 \mathrm{kDa}$ reappeared, suggesting a "de novo" synthesis process. In addition, other protein bands (between 20 and $45 \mathrm{kDa}$ ) were preserved during the growth of the cotyledon calli (Fig. 4-A2).

The data on amino acid content of the cotyledon calli powder revealed that such as soybean seeds powder, calli proteins are well balanced in the essential amino acids, except slightly limiting in cystine, methionine and tryptophan are the conspicuous limiting amino acids (Table 1). These results are comparable to data reported for $G$. wightii seeds flour (VISWANATHAN et al., 2001) and other soybean cultivars (VASCONCELOS et al., 1997). Cotyledon calli flour showed a high percentage of aspartic acid/asparagines. Others amino acids showed similar values.

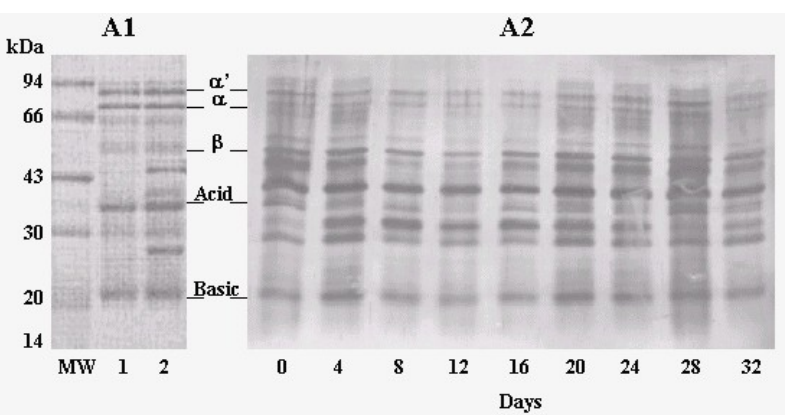

FIGURE 4 - SDS-PAGE analysis. (A1): Molecular weight markers (MW) - phosphorylase b $(94 \mathrm{kDa})$, bovine serum albumin (66 kDa), ovalbumin (43 kDa), carbonic anhydrase (30 kDa); soybean typsin inhibitor (20 kDa), $\alpha$-lactalbumin (14 kDa); Soybean (Glycine max) seeds powder (lane 1); Glycine wightii cotyledons powder (lane 2). (A2): Glycine wightii cotyledon callus colleted during growth curve $(0$, 4, 8, 16, 20, 24, 28 and 32 days).

TABLE 1 - Amino acid composition of cotyledon callus powder from Glycine wightii.

\begin{tabular}{cc}
\hline Amino acid & Residues $(\%)$ \\
\cline { 2 - 2 } Cotyledon callus \\
\hline Asx & 38.90 \\
Thr & 3.02 \\
Ser & 5.98 \\
Glx & 5.67 \\
Gly & 6.31 \\
Ala & 6.60 \\
Half-Cys & 0.36 \\
Val & 3.83 \\
Met & 0.05 \\
Ile & 2.32 \\
Leu & 3.46 \\
Tyr & 2.76 \\
Phe & 3.55 \\
His & 2.48 \\
Lys & 4.64 \\
Arg & 2.70 \\
Pro & 7.33 \\
Trp & 0.64 \\
\hline
\end{tabular}




\section{CONCLUSION}

Our results suggest that callus culture provides an interesting model system to investigate the dinamic of protein biosynthesis, thus providing a clue to their physiological functions. Moreover, by knowing which proteins are being synthesized in callus culture obtained from different explants and stages of growth and can lead to identifying the role of these proteins.

\section{ACKNOWLEDGMENTS}

This work was supported by grants from the Conselho Nacional de Desenvolvimento Científico e Tecnológico (CNPq).

\section{REFERENCES}

BLUM, H.; BEIER, H.; GROSS, H. J. Improved silverstaining of plant proteins, RNA and DNA in polyacrylamide gels. Electrophoresis, [S.1.], v. 8, p. 93-99, 1987.

BRADFORD, M. M. A rapid sensitive method for quantitation of microgram quantities of protein utilizing the principle of protein-dye binding. Analytical Biochemistry, New York, v. 72, p. 248-254, 1976.

BROOKS, J. R.; MORR, C. V. Current aspects of soy protein fractionation and nomenclature. Journal of the American Oil Chemists'Society, Chicago, v. 62, p. 1347-1354, 1985.

FIGUEIREDO, M. B. The real identity of the soybean rust in Brazil. Summa Phytopathology, Jaguariuna, v. 26, n. 2, p. 197-200, 2000.

GUPTA, N.; SRIVASTAVA, P. S. Purification and chacterization of a lectin from seeds and cotyledonary callus of Zizyphus mauritiana. Plant Cell Report, [S.l.], v. 17, p. 552-556, 1998.

GUTMANN, M.; ADERKAS, P. von; LABEL, P.; LELU, M. Effects of abscisic acid on somatic embryo maturation of hybrid larch. Journal of Experimental Botany, Oxford, v. 47, p. 1905-1917, 1996.

HAMMATT, N.; NELSON, R. S.; DAVEY, M. R. Plant regeneration from seedling explants of perennial Glycine species. Plant Cell, Tissue and Organ Culture, Dordrecht, v. 11, p. 3-11, 1987.
LAEMMLI, U. K. Cleavage of structural proteins during the assembly of the head of bacteriophage T4. Nature, London, v. 227, p. 680-685, 1970.

LAL, N.; CHANDRA, P.; SINGH, J.; SINGH, H. N. Changes in nucleic acid and protein contents during plant regeneration from callus in sugarcane. Indian Journal Plant Physiology, New Delhi, v. 35, p. 389-392, 1992.

MURASHIGE, T.; SKOOG, F. A revised medium for rapid growth and biossays with tobaco tissue cultures. Physiologia Plantarum, Copenhagen, v. 15, n. 3, p. 473479, 1962.

PANDEY, P.; BANSAL, Y. K. Plant regeneration from leaf and hypocotyl explants of Glycine wightii (W. and A.) Verdc. var long. Japan Journal Breed, Tokio, v. 42, p. 1-5, 1992.

PINTÉR-SZAKÁCS， M.; MOLNÁR-PERL， H. Determination of tryptophan in unhydrolyzed food and feedstuffs by the acid ninhydrin method. Journal of Agricultural and Food Chemistry, Easton, v. 38, p. 720726, 1990.

PODDER, K. S.; D'SILVA, I.; VAIDYANATHAN, C. S. Ribosome-inactivating proteins and agglutinins from callus and suspension cultures of Ricinus communis L. and Abrus precatorius L. Plant Science, Shannon, v. 94, p. 161-172, 1993.

SAARE-SURMINSKI, K.; PREIL, W.; LIEBEREI, R. Arabinogalactan proteins in embriogenic and nonembryogenic callus cultures of Euphorbia pulcherrima. Physiologia Plantarum, Copenhagen, v. 108, p. 180-187, 1999.

SCRAGG, A. H.; ALLAN, E. J. Picrasma quassioides Bennet (Japanese quassia tree): in vitro culture and production of quassin. In: BAJAJ, Y. P. S. (Ed.). Biotechnology in agriculture and foresty: medicinal and aromatic plants. Berlin: Springer-Verlag, 1993. v. 21, p. 249-268.

SERRA, A. G. P.; PAIVA, R.; PAIVA, P. D. O. Analises bioquímicas de calos formados de explantes foliares de castanha-do-Brasil (Bertholletia excelsa H. B. K.). Ciência e Agrotecnologia, Lavras, v. 24, p. 833-840, 2000. 
SILVA, A. L. C.; CARUSO, C. S.; MOREIRA, R. A.; HORTA, A. C. G. In vitro induction of callus from cotyledon and hypocotyl explants of Glycine wightii (Wight \& Arn.) Verdc. Ciência e Agrotecnologia, Lavras, v. 27, n. 6, p. 1277-1284, 2003.

SMITH, R. M. Plant tissue culture: techniques and experiments. San Diego: Academic, 2000. 231 p.

SHUTTUCK-EDIDENS, D. M.; BEACHY, R. N. Degradation of b-conglycinin in early stages of soybean embryogenesis. Plant Physiology, Washington, v. 78, p. 895-998, 1985.
VASCONCELOS, I. M.; SIEBRA, E. A.; MAIA, A. A. B.; MOREIRA, R. A.; FERREIRA NETO, A.; CAMPELO, G. J. A.; OLIVEIRA, J. T. A. Composition, toxic and antinutritional factors of newly developed cultivars of brazilian soybean (Glycine max). Journal of the Science of Food and Agriculture, London, v. 75, p. 419-426, 1997.

VISWANATHAN, M. B.; THANGADURAI, D.; RAMESH, D. Biochemical and nutritional evaluation of Neonotonia wightii (Wight \& Arn.) Lackey (Fabaceae). Food Chemistry, London, v. 75, p. 275-279, 2001. 